\title{
Impact of Temperature, Rainfall and Clearness Index on Global Solar Radiation at Nepalgunj in Nepal

\author{
Bed Raj K.C. ${ }^{1}$
} \\ ${ }^{1}$ Associate Professor, Mahendra Multiple Campus, Tribhuvan University, Nepalgunj, Nepal
}

\section{Corresponding Author}

Bed Raj K.C.

Email: bedrajkc@yahoo.com

\begin{abstract}
This paper reports the first experimental results on global solar irradiance measured at the horizontal surface since 2017 using calibrated Pyranometer-2 at Nepalgunj (Lat.28.05 $\mathrm{N}$, Lon. $81.62^{\circ} \mathrm{E}$ ) which is about $150 \mathrm{~m}$ from the sea level. This paper explains the impact of temperature, rainfall and clearness Index on the intensity of global solar irradiation. The annual average measured value of GSR $16.02 \mathrm{MJ} / \mathrm{m}^{2} /$ day which is sufficient to promote solar active and passive solar energy technology at Nepalgunj and other similar geographical locations. The results of this research can be utilized for the conformation of variation of solar radiation with meteorological parameters and can be used for location of similar meteorological and geographical sites where solar data are not available.
\end{abstract}

\section{KEYWORDS}

Atmospheric pollution, Clearness factor, Global irradiance, Variation factors

\section{INTRODUCTION}

The sun is radiating its own energy at the rate of $3.9 \times 10^{26} \mathrm{~J} / \mathrm{sec}$ in all directions. This huge

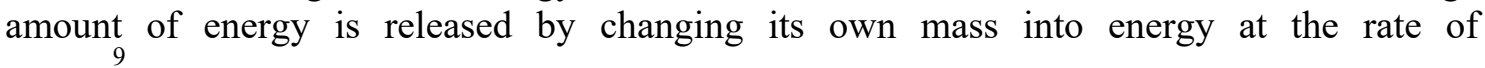
$4.5 \times 10 \mathrm{~kg} / \mathrm{sec}$ (Salby, 1996). The basic ingredients of this little star are hydrogen contained element deuterium (D) and inert gas element helium (He). The conversion of four hydrogen atoms to one Helium atom in fusion reaction and large amount of energy is released. As per quoted by WECS (1995), 78\% of the land area of Nepal lies in high potential solar energy insolation areas. The average solar radiation varies from $3.6-6.2 \mathrm{kWh} / \mathrm{m}^{2} /$ day, and the sun shines for about 300 days in a year over the targeted area for study in Nepal (Adhikari et al., 2013). The development of technology for solar energy production is thus reasonably favorable in many parts of our country Nepal. Solar energy is used in traditional way for drying crops, clothes, fuel wood, crop residues etc. The technology for the production of domestic solar water heaters was invented in the sixties. The solar water heaters are mainly used in the urban centers and during the trekking route. About 61,000 solar heaters were installed in the country house-wisely till 2005. Agricultural products such as paddy, wheat, maize, fruits, vegetable and herbal medicines are dried in open air in Nepal which is traditional drying method for storage. Cabinet type, rack type and tunnel type solar dryers are also used besides natural sun drying in some places here in Nepal. Few designs of solar dryers in the country are manufactured by few manufacturers and NGOs. RECAST developed a modified rack type solar dryer used for drying fruits and vegetables. By providing subsidies the government has been trying to encourage the use of solar dryers. AEPC announced 50\% subsidy on the cost of solar dryer in 1998. In Nepal RECAST developed solar cookers in parabolic form in 1997. Locally, later on RECAST developed box 
type solar cookers. Some cookers were distributed and a number of demonstrations and training sessions were conducted on these devices. The subsidy also provided by the local government in assistance for the supply of a parabolic solar cooker (Bastola, 2017). The use of solar photovoltaic cell is increasing rapidly in the country after the provision of subsidy by the local Government agency here in Nepal. This technology for electricity generation has been widely used for in households, telecommunications, airports etc. There are around 30 registered solar PV companies operating for the dissemination of SHS with hundreds of branch offices in the various district and rural areas of Nepal. Till 2005 year, 90,172 units of SHS had been installed in the country (APCTI, 2008). For estimation global solar radiation and evaluation of the insolation potentials of rural areas where measured global solar radiation data may not be available due to climatic parameters and for the same difference in effects maximum, minimum temperatures and sun shine hours are used for possible photovoltaic (PV) applications, thus to find out the mean value with respect to day and night shown weathers (Chineke, 2009).

There is enough research on solar energy potential and utilization of it around the world. Solar radiation at other region of Nepal is also measured though, not any research has been found in Mid-western region of Nepal on solar source of power. Thus, a held research is proposed to fill out the gap in the existing literature.

Solar energy is at present becoming more and more popular as the oil prices are getting so kept as for increasing (Energy Efficiency and Conservation Agency, 2001). The demand of coal, oil and gas continues to grow on a daily basis the worldwide. These types of inflammable fuel are increasing global warming, ozone depletion and air pollution too because of heat and temperature allied with carbon dioxide in the smokes formed after burning hydrocarbons and other organic substances as fuel. So, solar power is one of the best alternatives which provide solutions of above problems to living in a modern ecological setting. Solar power is however understood practically the cleanest renewable energy for today (KC, 2016).

Sustainable energy is provided by solar technologies such as solar thermal and photovoltaic (PV) technologies. These are modular in nature and are therefore adaptable to a variety of applications varying in size, output temperatures and other operating requirements. Solar technologies are obtained by capital intensive in the case of PV; solar technologies rely on a freely available source and have extremely low maintenance costs. For turning on navigation lights, in telecom sites and isolated or remote areas of world PV may be the source in low maintenance. The solar thermal and solar PV technologies have lifetimes greater than 25 years. Minimum manufacturer guarantee of solar PV modules is about 20 years. Most power plants are either conventional or new. In case of new or existing buildings solar technologies are easily integrated. Due to architectural appearances buildings are often considered a positive asset due to their green image. The solar thermal and solar PV technologies show a large potential for cost reduction in the near future due to technological advancements and increased productions of power rich infrastructure based on substantial market expansion strategy $(\mathrm{KC}, 2017)$.

\section{Study Area}

The study site Nepalgunj represents Lowland region of Nepal. Solar radiation data of this site are used in the present analysis. Nepalgunj is in Banke district which is a SubMetropolitan municipality of Nepal situated on the Terain plains near southern border with Utter Pradesh of India. It is situated at an altitude of $150 \mathrm{~m}$ from the sea level. Nepalgunj is the business and tourism hub of western part of Nepal. It is the gateway to Mansarobar, Mount Kailash, amazing beautiful lake Phoksundo, Lake Rara and to some of the world's 
most beautiful scenic and adventurous trekking routes. It has a sub-tropical climate. Temperature highly affects the lifestyle of Nepalgunj. In summer season, temperature reaches up to $44^{\circ} \mathrm{C}$. But in the winter season cold, foggy and haze, the temperature may drop to $4^{\circ} \mathrm{C}$. The district, located in midwestern Nepal with Nepalganj as its district headquarters, covers an area of 2,337 $\mathrm{km}^{2}$ and had a population of 385,840 in 2001 and 491,313 in 2011. (CBS, 2011). There are three main cities in the Banke District: Nepalganj, Kohalpur and Khajura Bajaar (Figure 1).

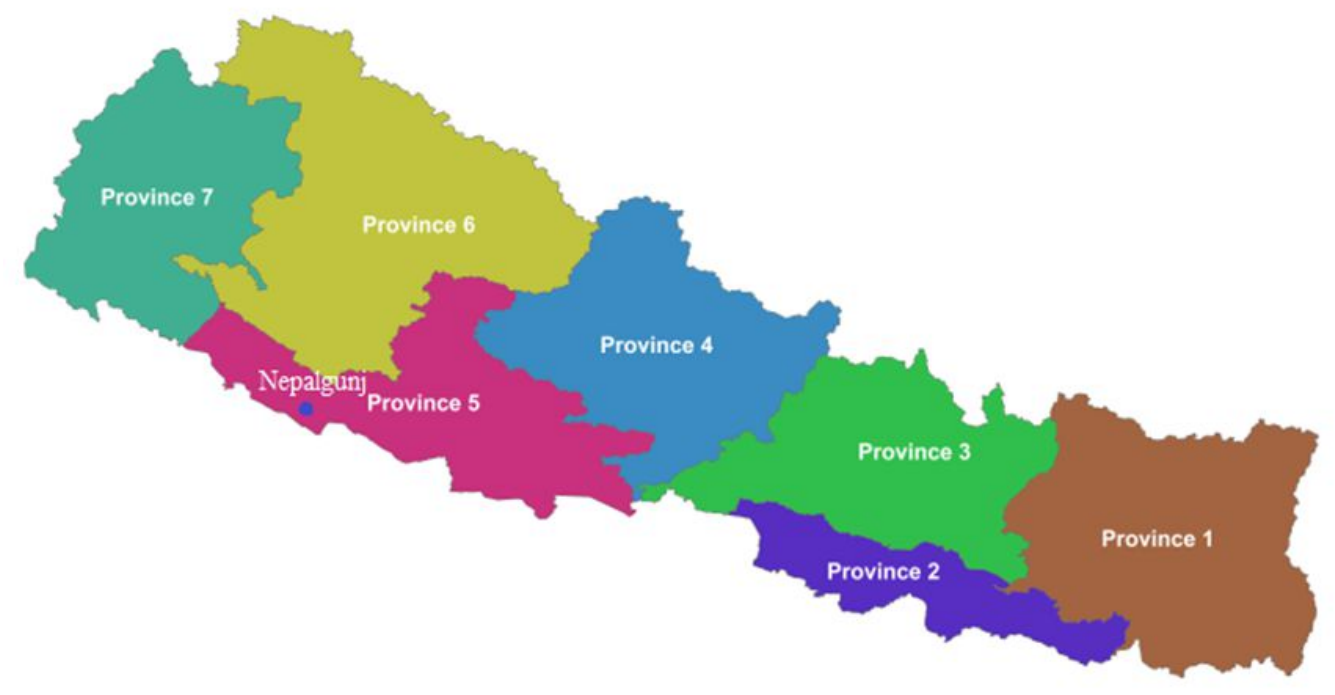

\section{Figure 1: The map of Nepal showing seven provinces.}

\section{Instrument and Methods}

The primary data of daily solar radiation and temperature on horizontal surface for Nepalgunj were measured by using Pyranometer-2 (Figure 2). This instrument is installed at Mahendra Multiple Campus Nepalgunj $\left(28.05^{\circ} \mathrm{N}, 81.62^{\circ} \mathrm{E}\right)$. Daily sunshine duration and relative humidity data for this site were obtained from the Department of Hydrology and Meteorology, Government of Nepal. The data obtained covered a period of years from 2016 year. The most widely used ORIGIN/Microsoft Office Excel software has been used for the data analysis.

\section{Figure 2: The Pyranometer-2}

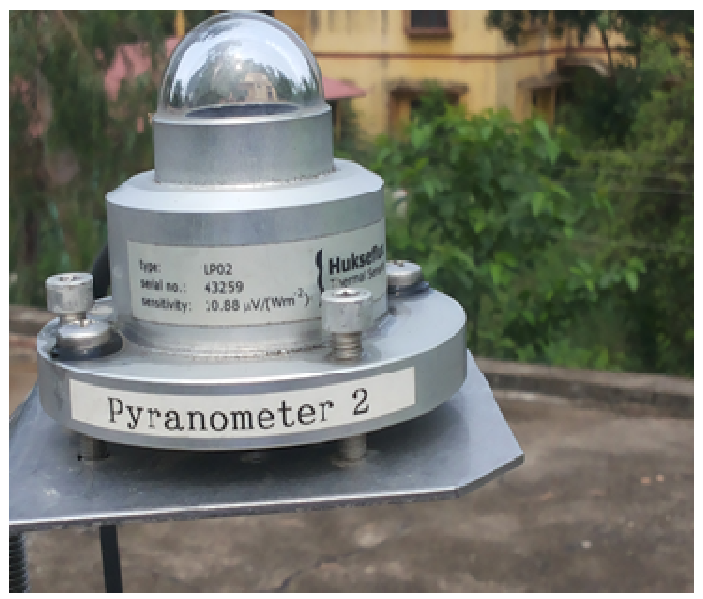

Spectral range of Pyranometer-2 is 0.35 to $1.5 \times 10^{-6} \mathrm{~m}$ and Sensitivity is $10.88 \mu \mathrm{V} / \mathrm{W} / \mathrm{m}^{2}$. 
It has $18 \mathrm{~s}$ response time. Temperature dependence of sensitivity is $\left(-10{ }^{\circ} \mathrm{C}\right.$ to $\left.+40{ }^{\circ} \mathrm{C}\right) \pm 3 \%$ and operating temperature range is $-40{ }^{\circ} \mathrm{C}$ to $+80{ }^{\circ} \mathrm{C}$. Maximum solar irradiance is 2000 $\mathrm{W} / \mathrm{m}^{2}$.

A pyranometer measures the solar radiation received by a plane surface from a $180^{\circ}$ field of view angle. This quantity, expressed in $\mathrm{W} / \mathrm{m}^{2}$, is called "hemispherical" solar radiation. The solar radiation spectrum extends roughly from 285 to $3000 \times 10^{-9} \mathrm{~m}$. Pyranometer's main component is a thermal sensor with black coating. It has a flat spectrum covering the 200 to $50000 \times 10^{-9} \mathrm{~m}$ range, and has a near-perfect directional response. The coating absorbs all solar radiation and, at the moment of absorption, converts it to heat. The heat flows through the sensor to the sensor body. The thermopile sensor generates a voltage output signal that is proportional to the solar irradiance.

Source: www.hukseflux.com

\section{RESULT AND DISCUSSION}

\section{Seasonal Variation of Global Solar Radiation at Nepalgunj}

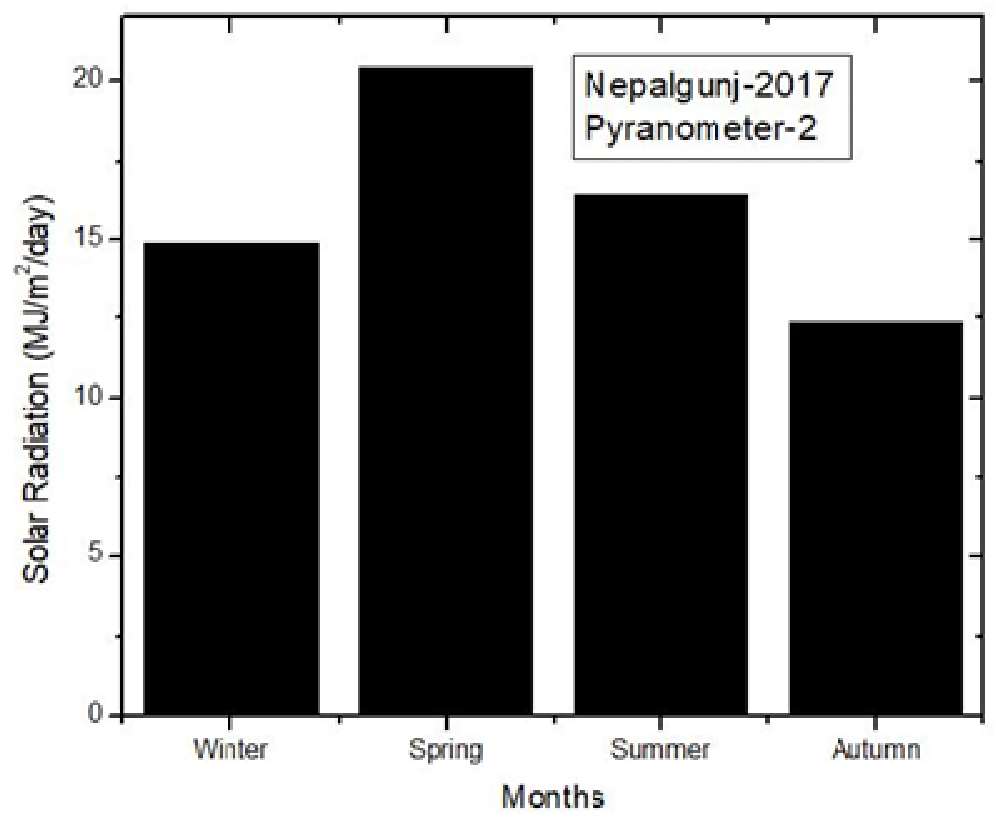

Figure 3: Seasonal variation of Global Solar Radiation at Nepalgunj for the year 2017 (using Pyranometer 2)

The GSR of Nepalgunj is $14.90,20.40,16.42$ and $12.38 \mathrm{MJ} / \mathrm{m}^{2} /$ day was found in winter, spring, summer and autumn seasons respectively. In this region, the maximum and minimum amount of GSR are obtained on spring and autumn which is similar as in other regions of Nepal. High value of GSR in spring is found due to lower value of solar zenith angle and clear sky days (Poudyal, 2016). The annual average GSR $16.02 \mathrm{MJ} / \mathrm{m}^{2} /$ day is found at Nepalgunj (Figure 3). 
Variation of Global Solar Radiation with Temperature in 2017

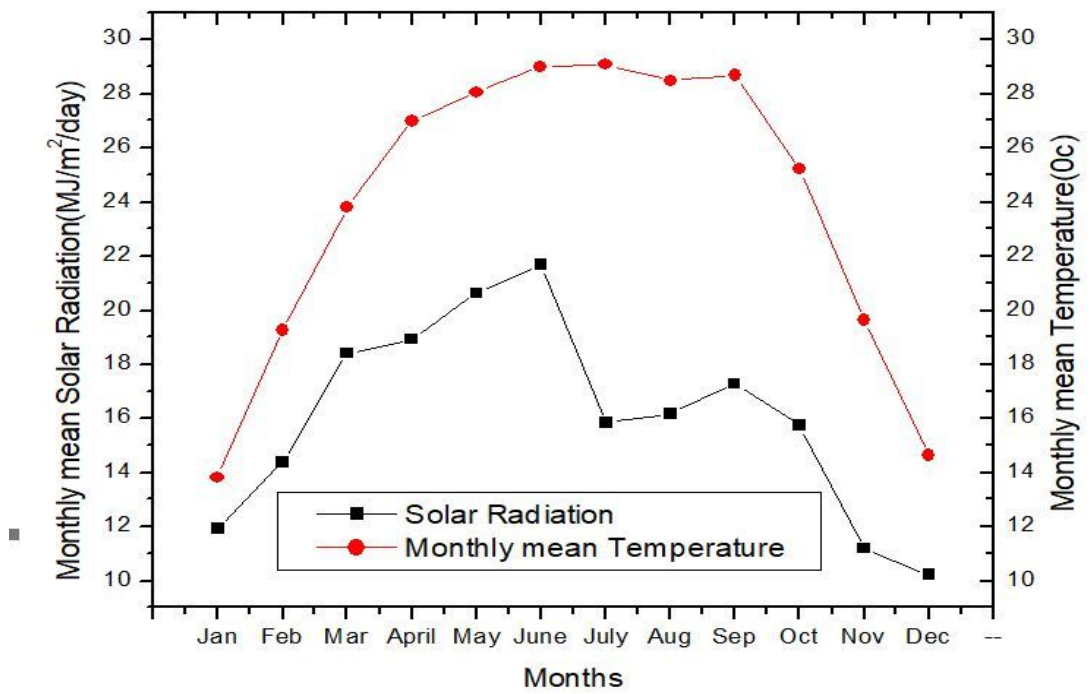

Figure 4: Monthly variation of Global solar radiation with Temperature in Nepalguni in 2017

From the Figure 4 it is observed that Global solar radiation varies with temperature throughout the year except in the summer due to rainfall in Nepalgunj. Cause of deviation of solar radiation with temperature is by precipitation and cloud (Poudyal, 2016).

\section{Variation of Global Solar Radiation with Rainfall in 2017}

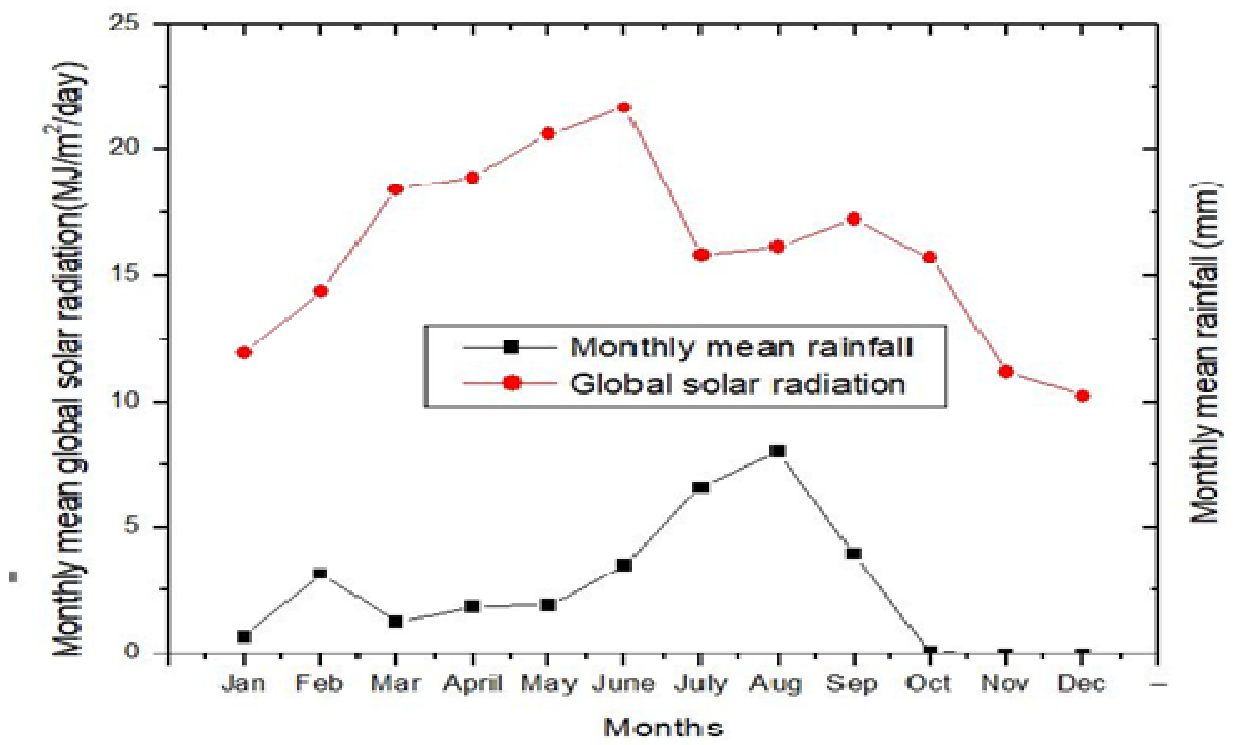

Figure 5: Monthly variation of Global solar radiation with rainfall in Nepalgunj in 2017

From the Figure 5 it is observed that Global solar radiation varies with rainfall. Maximum rainfall is observed on August so Global solar radiation is decreased. Cause of deviation of solar radiation is due to precipitation and cloud (Adhikari et al., 2013). 


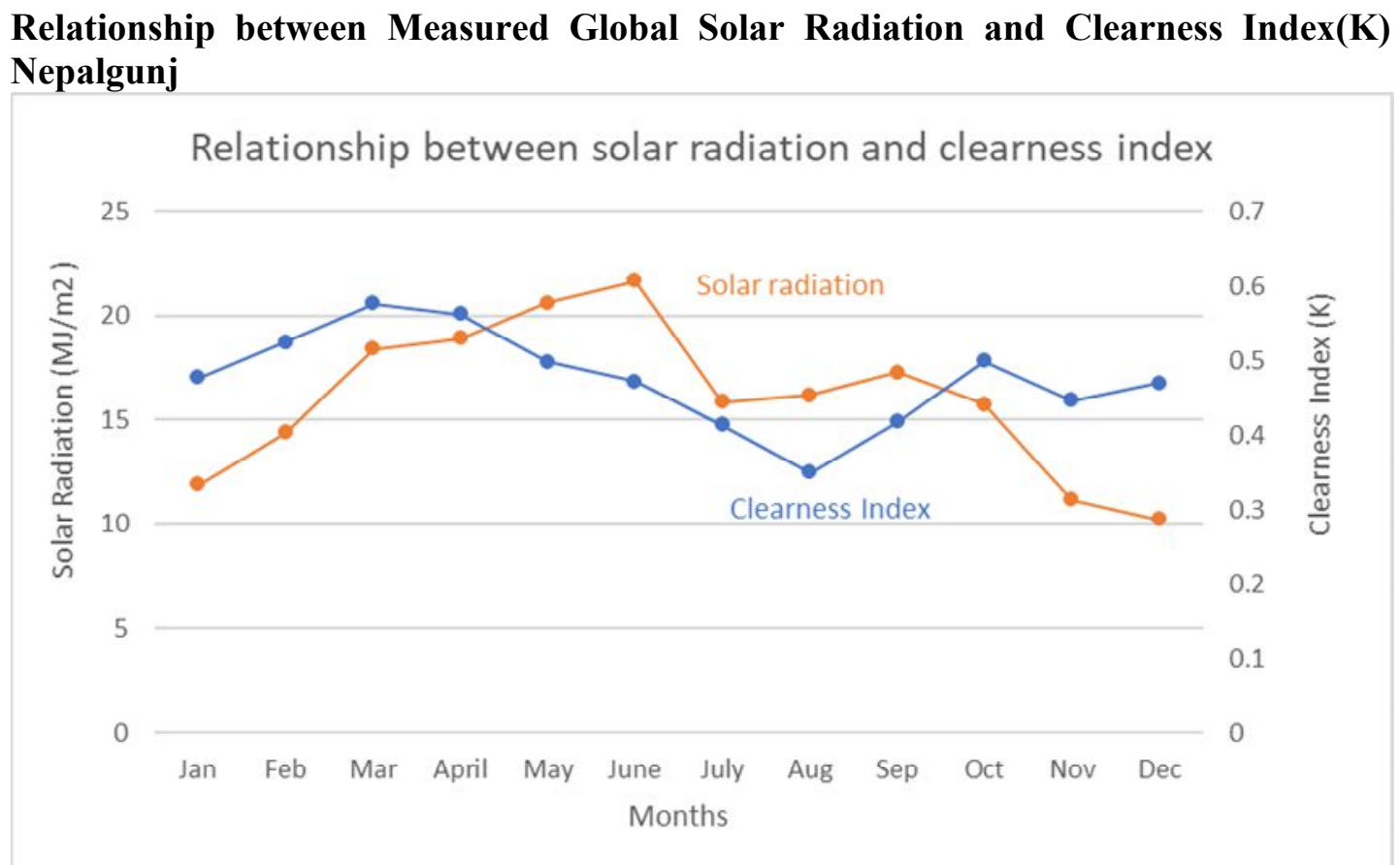

Figure 6: Relationship between Global Solar Radiation with clearness index at Nepalgunj for the year 2017

The relationship between Global Solar Radiation and Clearness Index is shown in Figure (6). The given figure indicates that there is maximum amount of solar energy can be harvested in spring season. The clearness index is the ratio of measured global solar radiation $\left(\mathrm{H}_{\mathrm{g}}\right)$ to the extraterrestrial solar radiation $\left(\mathrm{H}_{\mathrm{o}}\right)$. It is concluded that there is sufficient energy even at winter season.

\section{CONCLUSIONS}

It is found that the annual average GSR $16.02 \mathrm{MJ} / \mathrm{m}^{2} /$ day in Nepalgunj, the report showed that such amount of energy is sufficient to promote grid connected solar photovoltaic (PV) for power generating plants in Nepalgunj. The global solar radiation varies from month to month and season to season depending on temperature and precipitation. The maximum and the minimum global solar radiation20.40 MJ/m ${ }^{2}$ and $12.38 \mathrm{MJ} / \mathrm{m}^{2}$ are found in spring and autumn season in Nepalgunj. However, low global solar radiation is measured in summer due to the cloud and rainfall at Nepalgunj. Hence the topography as well as local weather condition also plays a vital role for the estimation of global solar radiation in any part of the world including Nepal. This study recommends that Nepalgunj and places having similar altitude/geographical/meteorological parameters are suitable for solar farming activities in Nepal.

\section{Acknowledgements}

Author is grateful to express thanks to Nepal Academy of Science and Technology (NAST) Government of Nepal for installing Pyranometer in Mahendra Multiple Campus, Nepalgunj, Banke for measurement of solar radiation. The support provided by the Prof. Dr. Shekhar Gurung, Prof. Dr. Khem Narayan Paudyal, Prof. Dr. Indra Bahadur Karki and staffs of Department of Physics Mahendra Multiple Campus Nepalgunj is highly acknowledged. 


\section{REFERENCES}

Adhikari, K.R.,et al., 2013,"Estimation of Global Solar Radiation for Four Selected sites in Nepal Using sunshine hours, temperature and Relative Humidity",Jour of Power and Energy engineering, http://dx.doi.org/10.4236/jpee.2013.13003, 1, pp 1-9

Chineke, I. U. 2009,Evaluating the global solar energy potential at Uturu,. International Journal of Physical Sciences Vol. 4 (3), pp. 115-119,ISSN 1992 - 1950 (C) 2009 Academic Journals .

Iqbal, M. (1983). An Introduction to Solar Radiation, Academic Press, New York

KC, B.R., Gurung S. (2016). Estimation of Global Solar Radiation Using Sunshine Hours at Himalayan Region, Jumla, Nepal Peer Reviewed International Journal IJSD, Ranchi, India ISSN 2320-9283, Vol.4 (4), 13-24

KC, B.R., Poudyal K.N., Gurung S.(2016). Variation of Global Solar Radiation at different altitudes of Mid -Western Region, Nepal, Research Journal of Chemical Sciences E-ISSN 2231-606X Vol. 6(8), 24-28, August,2016

KC, B.R., Gurung S. (2017). Estimation of total solar radiation using RadEst3.0 0software at Jumla, Nepal, Springer -International Journal of System Assurance Engineering and ManagementDOI 0.1007/s13198-017-0625-5

K.N.Poudyal, B. K. (2009). Estimation of Global Solar Radiation using Pyranometer and NILU-UV IrradianceMeter at pokhara valley in Nepal. Journal of Institute of Engineering, pp 69-78.

LP02 manual v1605 and www.hukseflux.co

Meagher, D. (April 2012). China's energy use. Australian National University.

Mengas, H. O., Ertekin, C., Sonmete, M.H., 2006,"Evaluation of solar radiation models for Kong a Turkey",Energy conversion and Management 47 (2006). pp. 3146-73.

NEA. (2011). Nepal Electricity Authority Report. Ministry of Energy, Government of Nepal.

Poudyal, K. N., Daponte, P., Luca, D. V., Bhattarai, B. K., Sapkota, B. (2010). Study of Variation of Global Solar Radiation at different altitudes of Himalaya Region - A Case Study in Nepal, 17th Symposium IMEKO TC 4, 3rd Symposium IMEKO TC 19 and 15th IWADC Workshop, Instrumentation for the ICT Era, Kosice, Slovakia.

Salby, M. L., 1996, "Fundamentals of Atmospheric Physics",Vol. 61. International Geophysics Series, Academic Press.

Sukhera, M. B. and Pasha, M. A. R. (1987). Solar Radiation Maps for Pakistan, Pakistan Solar and Wind Technology, 4(2), 229 -238.

SWERA (2006). United Nation Environment Program Global Environment Facility, Solar and Wind Energy Resource Assessment in Nepal.

Tsering, L. (1991). Role of Solar and wind wnergy in Nepal. Kathmandu: Integral Centre for Integrated Mountain Development.

Water and Energy Commission Secretariat (2010). Energy Synopsis Report, Government of Nepal. . 